\title{
The UNVEILING OF LIFE: LITURGY AND THE LURE OF KITSCH
}

Author:

Johan Cilliers ${ }^{1}$

\section{Affiliation: \\ ${ }^{1}$ Department of Practical \\ Theology and Missiology, \\ Stellenbosch University, \\ South Africa}

Correspondence to:

Johan Cilliers

email:

jcilliers@sun.ac.za

\section{Postal address:}

Bon Chretien 16,

Stellenbosch 7600,

South Africa

\section{Keywords:}

theological aesthetics; simulation of beauty, goodness and truth; Milan Kundera; Umberto Eco; Jean Baudrillard

\section{Dates:}

Received: 15 Mar. 2010

Accepted: 01 Sept. 2010

Published: 16 Nov. 2010

How to cite this article: Cilliers, J., 2010, 'The unveiling of life: Liturgy and the lure of kitsch', HTS Teologiese Studies/ Theological Studies 66(2), Art. \#815, 5 pages. DOI: 10.4102/hts.v66i2.815

\section{This article is available} at:

http://www.hts.org.za

\section{Note:}

This article was initially delivered as a paper at the annual meeting of the Practical Theological Society of South Africa, held in Pretoria 21-22 January 2010.
(C) 2010. The Authors. Licensee: OpenJournals Publishing. This work is licensed under the Creative Commons Attribution License.

\section{ABSTRACT}

This article probes the classic definition of religious aesthetics as related to the notions of beauty, goodness and truth. The phenomenon of kitsch, understood as simulation (or inversion) of beauty, goodness and truth, is taken cognisance of, especially in the light of contributions by Milan Kundera, Umberto Eco and Jean Baudrillard. The article briefly reflects on the liturgical consequences when kitsch manifests itself as simulated 'beauty', 'goodness' and 'truth' and concludes with some considerations regarding the characteristics of kitsch.

\section{AESTHETICS: THE INTERPLAY OF BEAUTY, GOODNESS AND TRUTH?}

The unique relationship between art and theology has been debated extensively, especially since the eighties of the previous century. ${ }^{1}$ In terms of liturgy it has been pointed out that factors such as the anthropological basis of aesthetics (humans being created as being creative, having a neuro-cognitive capacity for imagination), the rediscovery of our bodileness, the upsurge of a culture of images and the imaginative mode of biblical texts all call for a rediscovery of the aesthetical dimensions of worship. It could indeed be said that liturgy - theology - cannot, and should not, be undertaken without a sound understanding of aesthetics (cf. Cillers 2007:55-78).

It is, however, not that easy to describe or define aesthetics as such, just as it is difficult, if not impossible, to define art. To reach an understanding of theological aesthetics proves to be an even more difficult task, given its distinctive understandings of beauty and (as) ugliness. Perhaps the classic understanding of the modes of God's revelation and therefore presence amongst us still offers the best vocabulary for this endeavour. It was Hans Urs von Balthasar (1982:30) who, especially during the 20th century, placed the concept of beauty back on the theological agenda. He argued that the praxis of God's presence among us, revealed in certain embodied encounters, is one of beauty. But what is meant by this?

Beauty is, of course, a classic aesthetical concept that had been brought into conjunction with God's revelation by theologians from the very beginning of Christianity. Classical thinkers such as Augustine and Aquinas, furthermore, categorised beauty alongside goodness and truth as being part and parcel of God's revelation to us, indeed as a perfect unity of beauty, goodness and truth (cf. Pastro 2005:56). Consequently,

Beauty, truth and goodness can never be separated. It is questionable whether we can ever know one except in intimate connection with the others.... There is a truth - a reality, an authenticity - about beauty and goodness. There is goodness - a wholesomeness, salutariness, sacredness - about both beauty and truth. There is beauty in truth - in its self-evidence, its simplicity, its transparency - and in goodness, especially in the comeliness of moral character.

(Avis 1999:78-79)

In my opinion, religious aesthetics could be understood within this dynamic interplay between beauty, goodness and truth. Where these dimensions of God's revelation coincide, an aesthetical event is constituted. And vice versa, where this interaction is compromised, aesthetics as such is shattered (German: verkitschen) and, in effect, superficialised. Then beauty becomes sentimentality, truth generalisations and goodness moral domestication. This superficialisation and inversion of aesthetics could also be called kitsch.

It should be noted here that the concepts of beauty, goodness and truth, and especially their interplay, cannot be separated from experiences of suffering and therefore from theodicy. It is my contention that theological kitsch comes to the foreground exactly when beauty, goodness and truth are taken out of the framework of theodicy to produce (simulate) a type of theologia gloriae that does not, and indeed cannot, take the dimension of suffering seriously. This needs some further clarification: In the brilliant novel by Milan Kundera (1984), The unbearable lightness of being, one of the characters, Sabina, has an epiphany in which she discovers that the world is slowly but surely being robbed of aesthetics, up to the point where beauty will entirely disappear from the earth:

... she discovered that the transformation of music into noise was a planetary process by which mankind was entering the historical phase of total ugliness. The total ugliness to come had made itself felt first as omnipresent acoustical ugliness: cars, motorcycles, electric guitars, drills, loudspeakers, sirens. The omnipresence of visual ugliness would soon follow... Before beauty disappears entirely from the earth, it will go on existing for a while by mistake. 'Beauty by mistake' - the final phase in the history of beauty.

(Kundera 1984:93, 101)

The discrepancy between life as 'lightness of being' and suffering as 'unbearable' compels Sabina to become sensitised for the process of omnipresent 'uglification'. This resonates with what the renowned philosopher Richard Kearny (1988:3) postulated: whilst Western civilisation is experiencing a boom in

1.To name but a few sources: Mennekes (1990, 1998); Dillenberger (1986, 1999); Thiessen (1999, 2001); Van Erp (2003) and Hacking (2005). Schmidt (2004:385) articulates this analogy between art and theology as follows: 'Kunst wie Religion sind damit Ausdruck von (2005). Schmidt (2004:385) articulates this analogy between art and theology as follows: 'Kunst wie Religion sind damit Ausdruck von
und Dialog über Erfahrung. Sie setzen in Bewegung. Und sie weisen über sich hinaus, sie verweisen auf etwas jenseits der unmittelbaren und Dialog über Erfahrung. Sie setzen in Bewegung. Und sie weisen über sich hinaus, sie verweisen auf etwas jenseits der unmit
Erfahrung.... Beiden, Kunst wie Religion kommt eine kairologisch-diagnostische wie eine kritisch-prophetische Bedeutung zu'. 
global communication, creativity as such is being endangered; while we are surrounded by images, imagination is dying out. Aesthetics - beauty, goodness and truth - seems to be under threat, seems to be in the process of being replaced (or rather: simulated) by kitsch.

From a theological viewpoint, I prefer to refer to this process not as uglification but rather as kitschification or plastification. In his monumental work On beauty, Umberto Eco (2004:72-85) has pointed out that 'ugliness' or 'monstrosity' has always been part and parcel of at least Western art. The notion of ugliness therefore does not (necessarily) oppose aesthetics. The popular television series Ugly Betty might be a case in point. While the main character, Ugly Betty, is depicted as the unattractive one in terms of outward appearances, in comparison with the glamorous people of the fashion world, she turns out to be the only one with compassion, the only one truly human. Only she truly understands (real) life. In effect, she becomes the attractive one, becomes Beautiful Betty. She becomes an inverted metaphor for 'as if': it is 'as if' she is ugly - but she is not!

This link between beauty and ugliness, however, goes deeper than Hollywood and is, in fact, of theological importance. The cross of Christ was 'ugly', and yet it embodies the strange 'aesthetics' of God. It has its own scandalous 'beauty'. It underlines the fact that that which we deem 'ugly' could in fact be 'beautiful'. This means that the Gospel of the (ugly) cross does not shrink away from the ugliness of life, does not gloss over it and does not try to dish up a sanitised version of it. Kitsch does exactly that. But the cross is not kitsch. Unfortunately, however, the cross can be kitschified, can be swept along in theological and liturgical strands that sentimentalise and sugarcoat it.

A relevant question for this article would therefore then be; To what extent, if any, has liturgy fallen prey to this upsurge of 'plastification', this lure of kitsch? It would indeed seem as if the primary threats facing liturgy are not only fundamentalism or postmodernism or secularisation or privatisation (cf. Pieterse 2008:1-8) but also plastification - a loss of aesthetics. With plastification an ideal of 'beauty' is held forth that is superficial and, in effect, inhuman. It becomes life-under-cosmetics, plaster of Paris existence, falsification with the pretence of originality. This process could also be called simulation.

\section{KITSCH: SIMULATION OF BEAUTY, GOODNESS AND TRUTH?}

If it is difficult to describe aesthetics and art, even more so is kitsch. Beauty is in the eye of the beholder. Kitsch also.

The word kitsch or kitch probably stems from a German word from the middle of the 19th century, with its trend towards sentimentality, from where it spread to almost all Western languages. It could mean 'trash' or perhaps rather denotes a socalled (simulated; as-if!) 'aesthetical' ideal to cleanse and sanitise life from all that smacks of suffering. The German expression etwas verkitschen means to 'knock something off', to shatter it. That which is good is knocked over, fragmented, spoiled under the illusion that the substitute is (still, or only now) the 'real thing'. In effect the 'real thing', or original, is perverted.

In the art world kitsch denotes works that are pretentious and inferior or in bad taste or merely vulgar. It is art that falls prey to the dictatorship of the populus and therefore to popular appeal. The notion of kitsch is traditionally also used in terms of a variety of other fields, such as literature, film and fashion. It usually applies to cheap works produced for the mass market, such as those found in souvenir shops and chain stores. Kitsch often denotes objects of such bad taste that they are actually 'good' in an ironic way, which explains the many collectors of good (bad) kitsch. Collecting kitsch has, in fact, become a booming 'art' in itself!
It remains a subjective exercise when it comes to the discernment of kitsch. While many people would, for instance, describe the painting The lost orchid by Tretchikoff as pure kitsch, thousands and even millions might not share this opinion and might proudly display prints of this in their homes.

The art of Tretchikoff, in fact, offers an interesting insight into what is understood as kitsch. Perhaps one could say that The lost orchid, for instance, does not constitute kitsch as such (at least in the eye of some beholders!). As a matter of fact, this painting could be seen as not offering a sugarcoated version of (the party of) life. The after-effects of the party are visible: the streamers, the smoked cigarette, the trampled, lost orchid. The orchid has fulfilled its purpose and now lies on a dirty pair of steps and, in fact, weeps her last water drops. This is life after the party, naked and unveiled.

But the kitschification of this art comes in with its transformation into a mass product, reproduced endlessly to find its place in the homes of masses. The copying and commercialisation of artworks like these often take place up to the point where people again long for the 'original', perhaps exemplified by the fact that this specific depiction of The lost orchid was sold for millions of rands but, at the same time, debunked by many art critics as a (very clever) falsification of the original! Perhaps this could even be called a double process of kitschification: it is a 'genuine copy' of the 'original; - or not!?

Generally art that falls into the category of kitsch may claim to have an aesthetic purpose but, in fact, is tawdry and mediocre. It is, in terms of what we said above, an inverted and simulated form of aesthetics that tries to wear the masks of beauty, goodness and truth. Herein lies the essence of kitsch: it presents itself 'as if' it is the original but, in fact, denies it. It sidesteps all that is truly human, sugarcoating it in a halo of sentimentalism. As a matter of fact, when kitsch flourishes, sentimentalism spurts forth like a fountain.

Nobody describes this sentimentalistic core of kitsch better than Milan Kundera (1984) in his The unbearable lightness of being:

Kitsch causes two tears to flow in quick succession. The first tear says: How nice to see children running on the grass! The second tear says: How nice to be moved, together with all mankind, by children running on the grass! It is the second tear that makes kitsch kitsch.

(Kundera 1984:251)

And even more directly,

... kitsch is the absolute denial of shit, in both the literal and figurative senses of the word; kitsch excludes everything from its purview which is essentially unacceptable in human existence

(Kundera 1984:248)

And perhaps most revealing, '... kitsch is a folding screen set up to curtain off death' (Kundera 1984:253).

With these insights Kundera has, in fact, captured the essence of theological (theologia gloriae) kitsch: it acts 'as if' death is not deadly. It veils death, as it veils the search for meaning amidst the suffering of life. The theology of the resurrection, on the contrary, accepts the deadliness of death completely and totally. It does not try to veil or conceal it but says, directly in the (unveiled) face of this deadliness, Where is your sting? (cf. 1 Cor 15:55)

Perhaps a workable definition of kitsch at this point would be the reduction or inversion of aesthetic objects or ideas into easily marketable forms. Some postmodern thinkers are of the opinion that the kitschification of culture is but one symptom of the postmodern condition. Jean Baudrillard (1998) describes kitsch as follows:

The kitsch object is commonly understood as one of that great army of 'trashy' objects, made of plaster of Paris or some such imitation 
material: that gallery of cheap junk accessories, folksy knickknacks, 'souvenirs', lampshades or fake African masks which proliferate everywhere, with a preference for holiday resorts and places of leisure.

(Baudrillard 1998:109-110)

Baudrillard (1998) goes on:

To the aesthetics of beauty and originality, kitsch opposes its 'aesthetics of simulation': it everywhere reproduces objects smaller or larger than life; it imitates materials (in plaster, plastic, etc.); it apes forms or combines them discordantly; 'it repeats fashion' without having been part of the experience of fashion.

(Baudrillard 1998:111)

Of importance here are the phrases aesthetics of simulation and repetition of fashion. In my opinion, these two key concepts of simulation and repetition bring us closer to the heart of the matter. Other key concepts would be the tendency to simplify and trivialise complex ideas by reducing them to stereotypes. It is furthermore clear that kitsch is oriented towards the masses and therefore tends towards the lowest common denominator to which all and sundry can relate; it is geared towards mass consumption and thus to profit-making entertainment. Or, again in the words of Baudrillard (1998),

This proliferation of kitsch, which is produced by industrial reproduction and the vulgarisation at the level of objects of distinctive signs taken from all registers (the bygone, the 'neo', the exotic, the folksy, the futuristic) and from a disordered excess of 'ready-made' signs, has its basis, like 'mass culture', in the sociological reality of the consumer society.

(Baudrillard 1998:110)

This tendency towards mass consumerism also implies that kitsch normally operates without any political or critical edge.

It would be interesting to ask what the relationship between kitsch and morality is. If kitsch, in fact, simulates and repeats up to the point where the simulation and repetition is seen as the 'original', does this not constitute aesthetical corruption? Is it not a form of unethical aesthetics? Should there be a connection between aesthetics and ethics? These questions cannot be addressed in extenso in this article. A few comments from a liturgical viewpoint might, however, be helpful.

Whilst many theologians have written extensively on the relationship between aesthetics and theology (and liturgy in particular), ${ }^{2}$ those giving attention to the phenomenon of kitsch, and its effects on theology and liturgy, seem to be extremely scarce. In order to do this, to reflect on the impact of kitsch on liturgy, we need to revisit our 'definition' of (religious) aesthetics in terms of beauty, goodness and truth.

\section{LITURGY AND THE LURE OF KITSCH}

\section{Kitsch as simulated 'beauty'}

In 2 Corinthians 3:13-16 Paul writes about the act of veiling and unveiling. He refers to Exodus 34:33-35 where Moses put a veil (kalymma) over his face because the Israelites feared the divine radiance that came from it. Paul, however, reinterprets this event to mean that Moses put on the veil so that the Israelites might not see the end of the temporary radiance. Paul then contrasts the passing glory (doxa) of the old covenant with the eternal glory of the new (verse 11). While the veil may not be lifted for many because of their disobedience to the Gospel, for Christian believers the veil has been lifted and they now see the light of the Gospel of the glory of Christ (2 Cor 4:4, 6; cf. Mundle 1976:213). We now look at life through the eyes of the Gospel. Liturgy celebrates, inter alia, this unveiling of life. Because the veil has been taken away by Christ, we can discern God's revelation,

2.A classic source in this regard still remains Guardini's work (1997). In the European context people like Barnard (2004) and Meyer-Blanck (2005) have debated this issue. It would seem as if this link between aesthetics and liturgy comes more naturally (corporally) in the African-American context (cf. McGann 2002). or again in terms of our definition, we gain (aesthetical) insight into and liturgically celebrate God's beauty, goodness and truth in this world.

Religious kitsch, on the contrary, being a phenomenon of veiling in its very essence, does not discern the beauty, in other words the coming and presence, of God within the realities of this life. This coming and presence (beauty) of God, or what Harries (1993:36) has called 'the glimmerings of eternal light, flames or flashes of divine beauty', is perverted into sentimental jargon; it is transformed into 'the pretty, the merely decorative, or the inoffensively pleasant' (Hart 2003:15). But the intention of this revealed beauty of God is more than merely evoking a sentimental feeling about pretty sunsets, artistic flower arrangements or snow-covered mountain tops. Beauty is all about the will of God and his intention with his creation, namely sjalom and wholesomeness (cf. Cilliers 2007:50). Therefore, the beauty of God includes the 'ugliness' of the cross, which represents the strange 'beauty' of God, par excellence (cf. Evdokimov 1990:309 f).

Religious kitsch changes God's beauty into sentimentality. The key concepts of Baudrillard again come to mind: the 'beauty' of the cross is funnelled through the demand of marketable form, in order to attain the largest common denominator, in order to achieve the highest profit-making entertainment. In the process, the crux of the cross is kitschified. One need not look far for such liturgical kitschifications: in many worship services the angels no longer cry out 'Holy, Holy, Holy - but rather Nice, Nice, Nice!' (cf. Tisdale 2001:182). A kitschified cross no longer drips blood but honey, no longer embodies pain but plastic, no longer mediates salvation but sentiment.

God is transformed into a principle that sounds 'correct', especially religious, and this principle is used as a guarantee for human excellence, in other words for the achievements of a 'theology of success'. This is such a radical vulgarisation of the Gospel that we should perhaps join in the seemingly harsh critique of Bohren (1979:155) (one of the few who reflected theologically on the phenomenon of kitsch) when he states that religious kitsch does not understand the judgment of God and therefore cannot express the grace of God. The irony is that through this domestication of God, religious kitsch itself becomes an expression of God's judgment. If a church is ruled by King Kitsch, this church stands under God's judgment.

\section{Kitsch as simulated 'goodness'}

Religious kitsch does not understand the meaning of God's revealed goodness, in other words healing grace. It overestimates humanity's potential for self-generated healing and therefore loses out on grace. It does not understand the concept of being a creature of God while at the same time being a beggar in need of grace (Luther). Grace is cheapened and perverted and becomes just another tool in our so-called 'pursuit of happiness'. What do we mean by this?

Again, Baudrillard (1998:111) comes to our aid when he states that kitsch '... repeats fashion without having been part of the experience of fashion'. Liturgical kitsch talks about God's grace without understanding an iota of it. It endeavours to simulate, to duplicate, but it cannot present the 'original' because it never was or never became part of it. But if liturgy no longer understands the uniqueness of grace but rather focuses on that which works as 'self-help' or is popular according to the taste of the day, religious kitsch surges forward and is characterised by overflowing 'descriptions' of worship, in other words grace instead of experiencing worship and grace itself.

Liturgical language and rituals then no longer express something elementary but rather talk and preach 'about' something. The performance (graceful effect) of the Gospel then becomes the 'performance' of religious speech. Indeed, when the 'performance' of the liturgist is of such a quality that the 
speaker becomes a mere observer, standing outside the event, kitsch reigns supreme. These kinds of observer, in fact, do not observe God, the living God, because they stand outside the engagement with this God. They are rather in harmony with the fashion of the day, with its disordered excess of 'ready-made' signs (Baudrillard 1998:110); they are tuned into the illusion of a 'doit-yourself society'.

Again, this simulation of goodness might seem appropriate, even (religiously) correct, but it is wrong. It does not understand that the scandal of the cross unveils the kitsch of self-help techniques. Ultimately, these techniques transform (simulates) God's goodness (grace) into moral domestications.

\section{Kitsch as simulated 'truth'}

Kitsch cannot endure life's struggles. It avoids theodicy like the plague. It cannot exist in the tension of the quest for meaning. It rather becomes a type of souvenir kitsch, souvenir faith: like sentimental figurines and artefacts it bypasses reality, also the reality of suffering, poverty and being truly human. It is, to quote Kundera $(1984: 248,253)$ again, in absolute denial of the shit of life and sets up its folding screen to curtain off death. It cannot look at the ugly beauty of the cross.

African kitsch (decorated tribal drums, figures embraced in 'ubuntu', neatly woven beads, etc.), although providing food on the table for many an entrepreneur, can also blind one to the realities of Africa: realities of poverty, HIV/AIDS and corruption.

[Indeed, the] great army of 'trashy' objects, made of plaster of Paris or some such imitation material: that gallery of cheap junk accessories, folksy knickknacks, 'souvenirs', lampshades or fake African masks which proliferate everywhere, with a preference for holiday resorts and places of leisure [can create the illusion of blissful life, but under this surface reality suffers].

(Baudrillard 1998:109-110)

Kitsch cannot face the truth. This is also the way in which religious (and liturgical) kitsch operates. It views life through rosy lenses. It bypasses the truth of reality and rather operates like souvenir stalls on tourist routes. Religious and liturgical kitsch indeed has no political or critical edge: it excels in acquiescence, not in disrupting the status quo. It cannot face the truth and will not speak the truth. When it does speak it may once again sound correct but, in fact, is wrong.

Because kitsch, also in its liturgical form, constitutes the hallmarks of sensationalism and entertainment and speaks the language of the fashionable, using the jargon of the masses to full effect, it does not understand the need for lament. It has no inclination towards taking obedience (the Torah) into the rhythms of everyday experiences, also those that call for lament. Liturgical kitsch knows nothing about the real struggles of life; theologically speaking, it has domesticated - plastified - eschatology (cf. Cilliers 2008:26-28). Indeed, for kitsch domestication is everything, making everything harmless, especially God. Truth is generalised, robbed of it sharp edge. The harsh judgment of Bohren (1979:156) once again seems appropriate: 'Kitsch is an expression of faith that bypasses truth. It is practiced heresy, manifestation of a falsified gospel, the embodiment of lying'.

\section{CHARACTERISTICS OF KITSCH}

How does kitsch achieve this inversion of beauty, truth and goodness? The keyword is indeed simulation. Kitsch as simulation has certain characteristics. I briefly refer to five.

Firstly, endless repetition (which should be distinguished from relevant and functional repetition) is implemented to create the illusion that this representation (of beauty, goodness and truth) is the ultimate reality. In this manner, reality is kitschified and thus falsified. On a linguistic and rhetorical level, kitsch indeed often manifests itself as meaningless repetitions and accumulations in a fruitless attempt to achieve 'effect'. The word alone is not trusted; therefore, words must be repeated endlessly.

Secondly, still on a linguistic and rhetorical level, kitsch does not understand the art of finding fitting images/metaphors/parables, often simply stringing them together, not understanding the power of a single, strong metaphor. Thus it creates subtexts, distracting from the (simple) word or Word. It intends to create effect through a multitude of images but, in effect, ends up by pulling the senses apart (cf. Cilliers 2008:27-28). It shatters (verkitschen) that which should have been simple, should have been claritas scripturae.

Thirdly, kitsch is masterful in the aping of forms or discordant combination of them. By this kind of liturgical kitsch I mean an unnuanced and theologically irresponsible adding and subtracting ('cut and paste') of elements to and from the liturgical repertoire. Symbols and rituals are introduced, left out, shattered and fragmented without taking cognisance of the theological context, motivations, historical setting and theological and anthropological issues being put on the table via these activities (Wepener \& Müller 2001:482, 489). Liturgical kitsch, in fact, thrives on these dynamics of clinical repetition; it is cut-and-paste liturgy par excellence.

Fourthly, kitsch simplifies and trivialises complex ideas by reducing them to stereotypes. It in fact oversimplifies life, glossing over paradoxes and therefore also flattens out the hard edges of Scripture, trivialising and domesticating it (cf. Brueggemann 1989:7). In the process it becomes untrue and unfaithful to life, handing out recipes and how-to-do-it's instead of wisdom and discernment. Baudrillard's (1998:111) comments again come back to haunt us: kitsch reproduces objects smaller or larger than life. It betrays reality.

Fithly, it is therefore no wonder that kitsch excels in both superlatives and diminutives, linguistic structures that, in fact, create realities 'smaller or larger than life'. Kitsch loves to use diminutives ('Dear congregation, the Gospel has the answer to all out little daily worries ....') or superlatives (life is absolutely 'wonderful'), which inevitably leads to loss of true contextualisation: reality is simply not like that. For kitsch, faith is either about the 'little Lord Jesus who lays down his sweet head' or the 'phenomenal and glorious manifestation of God's glory'. It only loves the little Lord Jesus because 'no tears He does make' and who becomes the cute and cuddly Christ of kitsch. Or it only embraces the glorious and grand revelations of the great God, revelations that lift us up and above the mundane. In between in die monotony and sufferings of life, kitsch finds no foothold.

The use of diminutives and superlatives is often accompanied by the excessive implementation of adjectives and tautologies, perhaps because there is, in fact, a deep uncertainty about the reality of the little Lord Jesus or the possibility of the glorious manifestation of God's glory and an unconscious need to boost this confession. Of course, one could object and say that this is overkill in interpretation on our part and that the use of adjectives like these is harmless. But that is exactly the point: in this case it makes the Christmas event harmless, unreal, and creates a false awareness that pushes the Christmas event into sentimental realms (cf. Bohren 1979:150-151). It widens the gap between what is perceived as the (unreal?) 'manifestation of God' and his (real?) presence in the monotony and sufferings of our existence.

In short, kitsch does not, in fact cannot, understand the presence of God (his beauty, goodness and truth) within the realities of life. Therefore, it cannot fathom the ugly beauty of the cross. 


\section{REFERENCES}

Avis, P., 1999, God and the creative imagination: Metaphor, symbol and myth in religion and theology, Routledge, London and New York

Barnard, M., 2004, De dans kan niet sterven: Gerardus van der Leeuw (1890-1950) herlezen [The dance cannot die: Gerardus van der Leeuw (1890-1950) re-read], Zoetermeer, Meinema.

Baudrillard, J., 1998, The Consumer Society: Myths and structures, Sage, London.

Bohren, R., 1979, 'Bemerkungen zu neuen Liedern [Comments on new hymns]', Evangelische Theologie 39, 143-159.

Brueggemann, W., 1989, Finally comes the poet: Daring speech for proclamation, Fortress, Minneapolis.

Cilliers, J.H., 2007, Binne die kring-dans van die kuns: Die betekenis van estetika vir die Gereformeerde liturgie [Within the circular dance of art: The meaning of aesthetics for Reformed liturgy], Sun Press, Stellenbosch.

Cilliers, J.H., 2008, 'Silence is golden. Liturgy beyond the edge of language', Practical Theology in South Africa 23(1), 19-35.

Dillenberger, J., 1986, A theology of artistic sensibilities: The visual arts and the church, Crossroad, New York.

Dillenberger, J., 1999, Images and relics: Theological perceptions and visual images in sixteenth-century Europe, Oxford University Press, Oxford.

Eco, U., 2004, On beauty: A history of a Western idea, Secker and Warburg, London.

Evdokimov, P., 1996, The art of the icon: A theology of beauty, Oakwood, Redondo Beach.

Guardini, R., 1997, The spirit of the liturgy, Crossroads, New York.

Hacking, J., 2005, 'Kunst en religie [Art and religion]', Wereld en Zending: Tijdschrift voor Interculturele Theologie 1, 4-17.

Harries, R., 1993, Art and the beauty of God: A Christian understanding, Mowbray, London.

Hart, D.B., 2003, The beauty of the infinite: The aesthetics of Christian truth, Eerdmans, Grand Rapids, MI.

Kearny, R., 1988, The wake of imagination: Ideas of creativity in Western culture, Hutchinson, London.

Kundera, M., 1984, The unbearable lightness of being, Faber and Faber, London.

McGann, M.E., 2002, 'Timely wisdom, prophetic challenge: Rediscovering Clarence RJ Rivers' vision of effective worship', Worship 76(1), 2-24.
Mennekes, F., 1990, 'Der Zweifel im Bild: Úber ein neues Zueinander von Religion und Kunst [Doubting images: New connections between religion and art]', in W. Schmied \& J. Schilling (Hrsg.), GegenwartEwigkeit: Spuren des Transzendenten in der Kunst unserer Zeit, pp. 41-47, Cantz, Stuttgart.

Mennekes, F., 1998, 'Interconnection: Religion and art', in R. Crumlin (ed.), Beyond belief: Modern art and the religious imagination, pp. 25-28, National Gallery of Victoria, Melbourne.

Meyer-Blanck, M., 2005, 'Theatralisch inspirierte Liturgie [Theatrically inspired liturgy] ', Pastoral Theology 94(4), 134-145.

Mundle, W., 1976, S v Veil, The new international dictionary of New Testament theology, vol. 2, The Paternoster Press, Exeter.

Pastro, C., 2005, 'Kunst in de katholieke kerk vóór en na het Tweede Vaticaans Concilie [Art in the Catholic Church before and after the Second Vatican Concilium]', Wereld en Zending: Tijdschrift voor Interculturele Theologie 1, 56-61.

Pieterse, H.J.C., 2008, 'Liturgy on the edge of community', Practical Theology in South Africa 23(1), 1-8.

Schmidt, P.F., 2004, "'Kunst gibt nicht das Sichtbare wieder, sondern macht sichtbar" [Art does not reflect the visibile, but makes visibile]', Diakonia: Internationale Zeitschrift für die Praxis der Kirche 35(6), 381-386.

Thiessen, G.E., 1999, Theology and modern Irish art, Columbia, Dublin.

Thiessen, G.E., 2001, 'Exploring a Locus Theologicus: Sacramental presence in modern art and its hermeneutical implications for theology', in L. Boeve \& J.C. Ries (eds.), The presence of transcendence, pp. 213-222, Peeters, Leuven.

Tisdale, L.T., 2001, 'Navigating the contemporary worship narrows: Channel markers for deep waters', in B.K. Blount \& L.T. Tisdale (eds.), Making room at the table: An invitation to multicultural worship, pp. 175-188, John Knox, Louisville, KY.

Van Erp, S., 2003, 'Fides quaerens imaginem. Esthetica als fundamentele theologie: Geloof op zoek naar beelden [Fides quaerens imaginem. Aesthetics as fundamental theology: Faith in search of images]', Tijdschrift voor Theologie 43, 15-39.

Von Balthasar, H.U., 1982, The glory of the Lord, Vol 1: Seeing the form, T and T Clark, Edinburgh.

Wepener, C. \& Müller, B.A., 2001, “"Liturgiese kitsch?" liturgiewetenskaplike verkenning van 'n Gereformeerde ritueel ["Liturgical kitsch?" - liturgical reflection on a Reformed ritual]', Nederduitse Gereformeerde Teologiese Tydskrif 42 (3\&4), 480-493. 